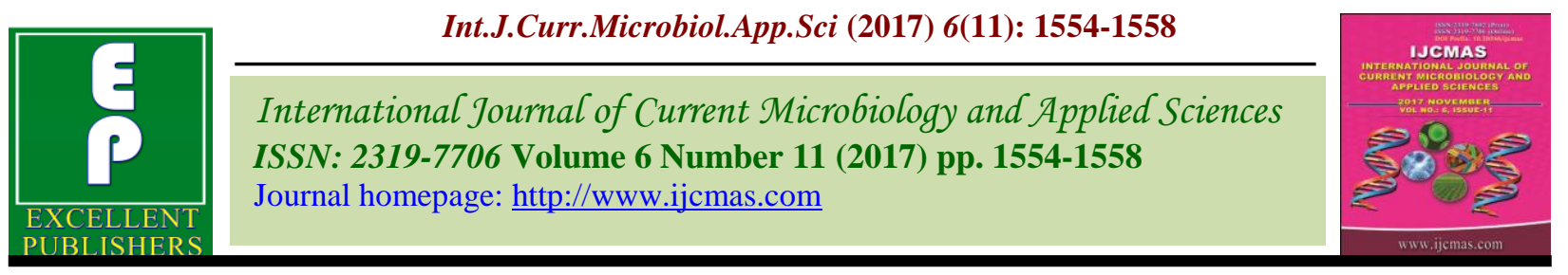

Original Research Article

https://doi.org/10.20546/ijcmas.2017.611.185

\title{
Screening of Okra Genotypes against Fusarium Wilt Disease
}

\author{
G.C. Nagesh ${ }^{*}$ and R. Mulge \\ Department of Vegetable Science, K.R.C. College of Horticulture, Arabhavi, \\ UHS, Bagalkot, Karnataka, India \\ *Corresponding author
}

\begin{tabular}{|c|c|}
\hline \multicolumn{2}{|r|}{ A B S T R A C T } \\
\hline & \multirow{8}{*}{ 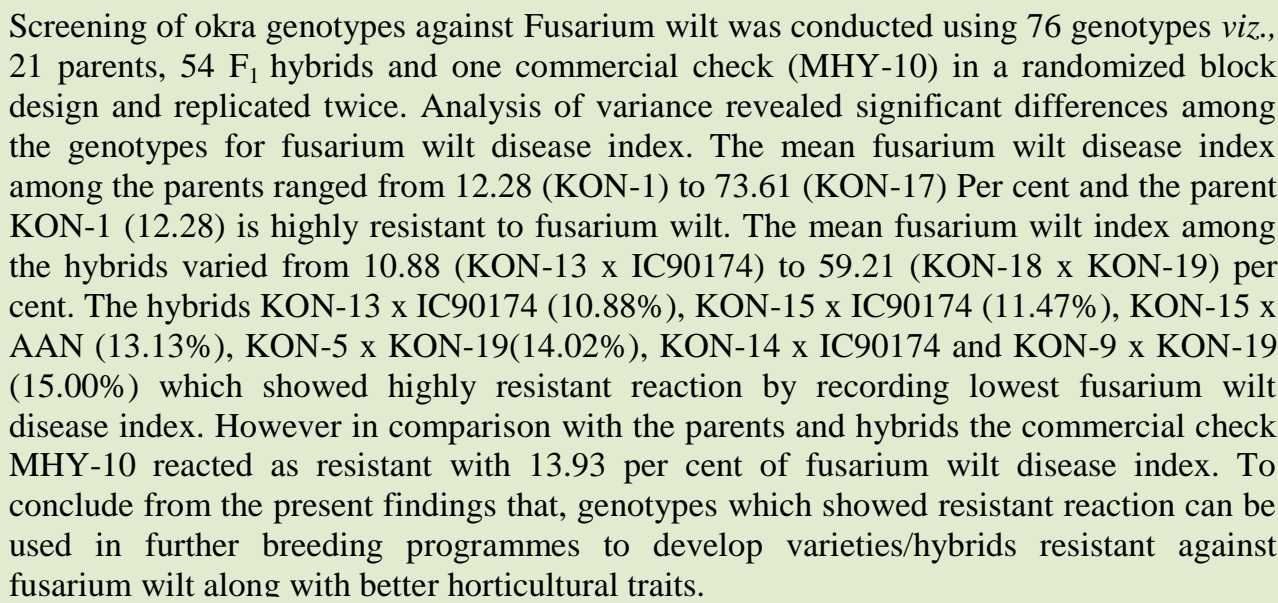 } \\
\hline Keywords & \\
\hline & \\
\hline $\begin{array}{l}\text { index, Parents and } \\
\text { hybrids. }\end{array}$ & \\
\hline Article Info & \\
\hline $\begin{array}{l}\text { Accepted: } \\
12 \text { September } 2017\end{array}$ & \\
\hline & \\
\hline & \\
\hline
\end{tabular}

\section{Introduction}

Okra [Abelmoschus esculentus (L.) Moench] belonging to the family Malvaceae is an important vegetable crop of the tropics and subtropics. Okra is specially valued for its tender, delicious green fruits which are cooked, canned and consumed in various forms in different parts of the country. India is the largest producer of okra covering an area of 0.530 million hectares with an annual production of 6.350 million tonnes (Anon., 2013). It is a potential export earner accounting for 13 per cent of export of fresh vegetables. Fusarium wilt, caused by the fungus Fusarium oxysporum f. sp. vasinfectum (Atk) Snyder \& Hansen, is one of the major diseases on Malvaceae species in Brazil. The pathogen causes vascular wilt in okra and cotton (Cia and Salgado 1997). The management of Fusarium wilt in Malvaceae hosts is difficult, and the main control strategy has been preventing the introduction of the pathogen in new planting areas (Davis et al., 2006). Other disease management methods are crop rotation and seed treatment with fungicides (Davis et al., 2006). Breeding and utilizing stable resistant cultivars against fusarium wilt has proven to be the most costeffective control method. However, literature is very scanty in the worldwide to employ the okra cultivars with resistance to fusarium wilt 
except the study conducted by (Aguiar et al., 2013) to identify the sources of resistance to fusarium wilt in okra. In the recent past fusarium wilt has become a serious constraint in okra growing areas of India. It causes severe losses if it affects at the early stage of the crop. At Arabhavi several lines have been developed through pedigree and bulk method of breeding. Fifty four $F_{1}$ hybrids were developed by crossing in a line $\mathrm{x}$ tester design. In this context, the present study was planned to identify the resistant sources among these genotypes against Fusarium wilt.

\section{Materials and Methods}

The investigation was conducted at the Department of Vegetable Science K.R.C. College of Horticulture, Arabhavi, Gokak Taluk, Belagavi district of Karnataka during the year 2013-2014. The experimental farm is situated in Northern Dry Zone of Karnataka state at $16^{\circ} 15^{\prime} \mathrm{N}$ latitude, $74^{\circ} 45^{\prime}$ E longitude and at an altitude of 612.03 meters above the mean sea level. The experimental material comprised 76 genotypes of which 21 parents viz., KON-1, KON-2,KON-3, KON-4, KON5, KON-6, KON-7, KON-8, KON-9, KON10, KON-11,KON-12, KON-13, KON-14, KON-15, KON-16, KON-17 and KON18(lines), and Arka Anamika (AAN), KON19 and IC90174(testers), $54 \mathrm{~F}_{1}$ hybrids and a commercial check (MHY-10). The experiment was laid out in randomized block design with two replications. Each treatment in each replication was represented by 20 plants at a spacing of $60 \times 30 \mathrm{~cm}$. However there are no standard screening methods to screen genotypes for fusarium wilt in okra. Fields heavily infested with Fusarium oxysporum f. sp. vasinfectum due to continuous planting of susceptible cotton have been used as a natural nursery to screen and select cotton cultivars and lines for FW resistance (Sanogo and Zhang, 2016). In our study genotypes were screened under natural field condition and they were evaluated for the disease reaction 20 days after sowing. For foliar symptoms the 0 - 4 rating scale was employed with slight modification were made from that of (Ulloa et al., 2006). $0=$ no foliar symptoms, $1=$ chlorosis and/or wilt restricted to cotyledons or first leaf, $2=$ chlorosis and/or wilt extending beyond the first leaf, $3=$ severe foliar symptoms on the entire plant, $4=$ dead Plant. From the grades, a disease index (DI) was calculated essentially as described by

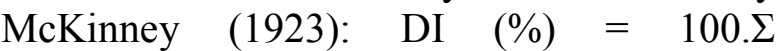
$[(\mathrm{f} . \mathrm{v}) /(\mathrm{n} . \mathrm{x})]$, where, DI $=$ disease index; $\mathrm{f}=$ number of plants with the same grade; $\mathrm{v}=$ observed grade; $\mathrm{n}=$ total number of plants evaluated and $\mathrm{x}=$ maximum grade on the scale. These DI data were grouped into classes according to the reaction to the pathogen observed in each accession with slight modification from that of (Reis et al., 2004): $0 \%=$ similar to an immune-like response $(\mathrm{SI}) ; 0.01-15 \%=$ highly resistant (HR); $15.01-30 \%=$ intermediate resistant (IR); 30.01-45\% = Tolerant (T); 45.01-55\% = Susceptible (S); and > 55\%= Highly Susceptible.

\section{Results and Discussion}

Analysis of variance revealed significant differences among the genotypes for fusarium wilt disease Index (Table 1). The mean fusarium wilt disease index among the parents ranged from $12.28(\mathrm{KON}-1)$ to $73.61(\mathrm{KON}-$ 17) Per cent. Among the parents, two reacted as highly susceptible, four as susceptible, nine as tolerant, five as intermediate resistant and only one parent KON-1 (12.28\%) is highly resistant to fusarium wilt. None of the parents and hybrids was immune to fusarium wilt (Table 2). The mean disease index among the hybrids varied from 10.88 (KON-13 x IC90174) to 59.21 (KON-18 x KON-19) per cent. 
Table.1 Analysis of Variance for fusarium wilt in okra

\begin{tabular}{|c|c|c|c|c|c|}
\hline $\begin{array}{c}\text { Source of } \\
\text { variation }\end{array}$ & $\begin{array}{c}\text { Degrees of } \\
\text { freedom }\end{array}$ & $\begin{array}{c}\text { Sum of } \\
\text { squares }\end{array}$ & $\begin{array}{c}\text { Mean sum of } \\
\text { squares }\end{array}$ & F cal & F prob \\
\hline Replications & 1 & 1102.618 & 1102.618 & 15.884 & 0.000 \\
\hline Treatments & 75 & 10806.053 & 144.081 & 2.076 & 0.001 \\
\hline Error & 75 & 5206.250 & 69.417 & - & - \\
\hline Total & 151 & - & - & - & - \\
\hline
\end{tabular}

Table.2 Reaction of okra genotypes to fusarium wilt disease

\begin{tabular}{|c|c|c|}
\hline Genotypes & Disease Index (\%) & Reaction * \\
\hline KON-1 & $12.28(20.20)$ & $\mathrm{HR}$ \\
\hline KON-2 & $35.58(36.40)$ & $\mathrm{T}$ \\
\hline KON-3 & $32.11(32.77)$ & $\mathrm{T}$ \\
\hline KON-4 & $39.90(38.94)$ & $\mathrm{T}$ \\
\hline KON-5 & $34.31(35.85)$ & $\mathrm{T}$ \\
\hline KON-6 & $38.52(37.96)$ & $\mathrm{T}$ \\
\hline KON-7 & $21.67(27.72)$ & IR \\
\hline KON-8 & $19.82(25.55)$ & IR \\
\hline KON-9 & $24.79(28.71)$ & IR \\
\hline KON-10 & $24.31(28.93)$ & IR \\
\hline KON-11 & $23.41(28.86)$ & IR \\
\hline KON-12 & $39.12(38.72)$ & $\mathrm{T}$ \\
\hline KON-13 & $38.54(38.34)$ & $\mathrm{T}$ \\
\hline KON-14 & $51.56(45.90)$ & $\mathrm{S}$ \\
\hline KON-15 & $44.81(41.13)$ & $\mathrm{T}$ \\
\hline KON-16 & $39.22(38.72)$ & $\mathrm{T}$ \\
\hline KON-17 & $73.61(59.09)$ & HS \\
\hline KON-18 & $50.20(45.12)$ & $\mathrm{S}$ \\
\hline AAN & $70.76(57.70)$ & $\mathrm{HS}$ \\
\hline KON-19 & $45.30(42.30)$ & $\mathrm{S}$ \\
\hline IC90174 & $45.07(42.05)$ & $\mathrm{S}$ \\
\hline KON-1 x AAN & $37.60(37.08)$ & $\mathrm{T}$ \\
\hline KON-1 x KON-19 & $28.13(31.06)$ & IR \\
\hline KON-1 x IC90174 & $22.84(28.55)$ & IR \\
\hline KON-2 x AAN & $36.88(37.31)$ & $\mathrm{T}$ \\
\hline KON-2 x KON-19 & $39.58(38.85)$ & $\mathrm{T}$ \\
\hline KON-2 x IC90174 & $25.27(29.95)$ & IR \\
\hline KON-3 x AAN & $33.08(34.68)$ & $\mathrm{T}$ \\
\hline KON-3 x KON-19 & $39.71(38.92)$ & $\mathrm{T}$ \\
\hline KON-3 x IC90174 & $26.19(30.40)$ & IR \\
\hline KON-4 x AAN & $25.39(30.04)$ & IR \\
\hline KON-4 x KON-19 & $17.68(24.83)$ & IR \\
\hline KON-4 x IC90174 & $33.17(34.87)$ & $\mathrm{T}$ \\
\hline KON-5 x AAN & $20.18(26.61)$ & IR \\
\hline KON-5 x KON-19 & $14.02(21.90)$ & HR \\
\hline KON-5 x IC90174 & $22.22(27.95)$ & IR \\
\hline KON-6 x AAN & $15.48(23.15)$ & IR \\
\hline KON-6 x KON-19 & $19.27(25.99)$ & IR \\
\hline KON-6 x IC90174 & $19.27(25.99)$ & IR \\
\hline
\end{tabular}


Table.2 Cotnd.......

\begin{tabular}{|c|c|c|}
\hline Genotypes & Disease Index (\%) & Reaction * \\
\hline KON-7 x AAN & $31.86(33.71)$ & $\mathrm{T}$ \\
\hline KON-7 x KON-19 & $23.61(28.83)$ & IR \\
\hline KON-7 x IC90174 & $34.72(35.35)$ & $\mathrm{T}$ \\
\hline KON-8 x AAN & $30.21(32.75)$ & $\mathrm{T}$ \\
\hline KON-8 x KON-19 & $37.50(36.95)$ & $\mathrm{T}$ \\
\hline KON-8 x IC90174 & $17.54(24.76)$ & IR \\
\hline KON-9 x AAN & $24.51(29.38)$ & IR \\
\hline KON-9 x KON-19 & $15.00(22.76)$ & HR \\
\hline KON-9 x IC90174 & $26.39(30.52)$ & IR \\
\hline KON-10 x AAN & $18.33(25.33)$ & IR \\
\hline KON-10 x KON-19 & $20.83(27.05)$ & IR \\
\hline KON-10 x IC90174 & $19.36(26.06)$ & IR \\
\hline KON-11 x AAN & $32.50(33.89)$ & $\mathrm{T}$ \\
\hline KON-11 x KON-19 & $53.66(47.10)$ & $\mathrm{S}$ \\
\hline KON-11 x IC90174 & $15.94(22.25)$ & IR \\
\hline KON-12 x AAN & $36.63(37.21)$ & $\mathrm{T}$ \\
\hline KON-12 x KON-19 & $39.02(38.65)$ & $\mathrm{T}$ \\
\hline KON-12 x IC90174 & $48.97(44.37)$ & $\mathrm{S}$ \\
\hline KON-13 x AAN & $28.64(32.25)$ & IR \\
\hline KON-13 x KON-19 & $33.64(34.96)$ & $\mathrm{T}$ \\
\hline KON-13 x IC90174 & $10.88(17.97)$ & HR \\
\hline KON-14 x AAN & $17.08(24.36)$ & IR \\
\hline KON-14 x KON-19 & $15.39(23.10)$ & IR \\
\hline KON-14 x IC90174 & $14.96(22.75)$ & HR \\
\hline KON-15 x AAN & $13.13(20.78)$ & HR \\
\hline KON-15 x KON-19 & $18.63(25.54)$ & IR \\
\hline KON-15 x IC90174 & $11.47(18.92)$ & HR \\
\hline KON-16 x AAN & $22.78(28.50)$ & IR \\
\hline KON-16 x KON-19 & $27.88(31.85)$ & IR \\
\hline KON-16 x IC90174 & $26.70(30.64)$ & IR \\
\hline KON-17 x AAN & $29.18(32.70)$ & IR \\
\hline KON-17 x KON-19 & $26.43(30.91)$ & IR \\
\hline KON-17 x IC90174 & $51.56(45.90)$ & $\mathrm{S}$ \\
\hline KON-18 x AAN & $38.64(38.43)$ & $\mathrm{T}$ \\
\hline KON-18 x KON-19 & $59.21(50.81)$ & HS \\
\hline KON-18 x IC90174 & $19.44(25.94)$ & IR \\
\hline CC (MHY-10) & $13.93(21.91)$ & HR \\
\hline F value & $2.07 * *$ & \\
\hline $\mathrm{CD} @ 5 \%$ & 16.59 & \\
\hline $\mathrm{CV}(\%)$ & 25.59 & \\
\hline
\end{tabular}

Note: The Values in the Parentheses are Arc Sine transformed.

HR- Highly Resistant, IR- Intermediate Resistant, T- Tolerant, S- Susceptible and HS- Highly Susceptible AAN- Arka Anamika

Among 54 hybrids studied one reacted as highly susceptible, three as susceptible, 15 as tolerant, 29 as intermediate resistant and six as highly resistant to fusarium wilt. The hybrids $\mathrm{KON}-13$ x IC90174 (10.88\%), KON-15 x IC90174 (11.47\%), KON-15 x AAN (13.13\%), KON-5 x
KON-19(14.02\%), KON-14 x IC90174 and KON-9 x KON-19 (15.00\%) which showed highly resistant reaction by recording lowest fusarium wilt disease index. However in comparison with the parents and hybrids the commercial check MHY-10 reacted as resistant 
with 13.93 per cent of disease index (Table 2). Aguiar et al., 2013, reported different levels of reaction to fusarium wilt in okra; this might be due to the different environmental conditions and genotypes used in their study. The line KON-1 and the hybrids which reacted resistant in the present study also recorded significant general combining ability effects and specific combining ability effects for some of the growth and yield parameters (Nagesh et al., 2014). Hence these genotypes can be further tested to confirm the level of resistance to fusarium wilt by screening under artificial epiphytotic conditions to use them as parental material in further breeding programmes to develop varieties/hybrids with good horticultural traits along with resistant to fusarium wilt.

The genotypes which showed resistant reaction can be efficiently utilized in further breeding programmes as superior pre-breeding material to accelerate the breeding work. Since there is no source of resistance, the new sources of resistance identified in the present study can be further exploited to achieve the durable resistance to fusarium wilt in okra.

\section{Acknowledgements}

I am greatly thankful to my major advisor and other technical staff in the division of vegetable science for timely guidance, support and providing facilities for conducting the experiment.

\section{References}

Aguiar, F. M., Micheref, S. M., Boiteux, L. S., and Reis, A., 2013, Search for sources of resistance to Fusarium wilt (Fusarium oxysporum f. sp. vasinfectum) in okra germplasm. Crop Breeding and Applied
Biotechnology, 13: 33-40.

Anonymous, 2013, Indian Horticultural Database, 2013. http://www.nhb.gov.

Cia, E. and Salgado, C. L., 1997, Doenças do algodoeiro (Gossypium spp.). In Kimati H, Amorim L, Rezende JAM, BergaminFilho A and Camargo LEA (eds.) Manual de fitopatologia: doenças das plantas cultivadas. 4th ed, v. 2, Agronomica Ceres, Sao Paulo, p 41-52.

Davis, R. M., Colyer, P. D., Rothrock, C. S. and Kochman, J. K., 2006, Fusarium wilt of cotton: population diversity and implications for management. Plant Disease, 90: 692-703.

McKinney, H. H., 1923, Influence of soil temperature and moisture on infection of wheat seedlings by Helminthosporium sativum. Journal of Agricultural Research, 26: $195-218$.

Nagesh, G. C., R. Mulge, V. Rathod, L. B. Basavaraj and S. M. Mahaveer, 2014, Heterosis and combining ability studies in okra [Abelmoschus esculentus (L.) Moench] for yield and quality parameters. The Bioscan, 9(4): 1717-1723.

Reis A, Giordano, L. B., Lopes, C. A. and Boiteux, L. S., 2004, Novel sources of multiple resistance to three races of Fusarium oxysporum f. sp. lycopersici in Lycopersicon germplasm. Crop Breeding and Applied Biotechnology, 4: 495-502.

Sanogo, S. and Zhang, J., 2016, Resistance sources, resistance screening techniques and disease management for Fusarium wilt in cotton. Euphytica, 207:255-271.

Ulloa, M., Hutmacher, R. B., Davis, R. M., Wright, S. D., Percy, R., and Marsh, B, 2006, breeding for Fusarium wilt race 4 resistance in cotton under field and greenhouse conditions. J Cotton Sci, 10:114-127.

\section{How to cite this article:}

Nagesh, G.C. and Mulge, R. 2017. Screening of Okra Genotypes against Fusarium Wilt Disease. Int.J.Curr.Microbiol.App.Sci. 6(11): 1554-1558. doi: https://doi.org/10.20546/ijcmas.2017.611.185 